\title{
Professional and career issues in administrative medicine
}

\author{
This article was published in the following Dove Press journal: \\ Journal of Healthcare Leadership \\ 30 October 2009 \\ Number of times this article has been viewed
}

\section{Arthur Lazarus \\ Senior Director, Global Clinical Development, AstraZeneca Pharmaceuticals, Wilmington, DE, USA}

Correspondence: Arthur Lazarus AstraZeneca LP, 1800 Concord Pike, B2B-704, PO Box 15437, Wilmington, DE 19850-5437, USA

$\mathrm{Tel}+\mathrm{I} 3028855452$

Fax + I 3028857787

Email arthur.lazarus@astrazeneca.com
Abstract: Administrative medicine is not recognized as a medical specialty in the United States, but increasingly, management-trained physicians are being recruited to fill important roles in hospitals and the life sciences industry. While the opportunities may be substantial, physicians who are interested in pursuing an administrative career should be aware of the challenges embodied in the role of physician executive, such as job turnover, alienation from peers, and overcoming the "caducean ceiling." Healthcare systems that are serious about transforming themselves must harness the energies of physicians as organizational leaders, and physicians who are equal to the task must supplement their medical training with training in business and management.

Keywords: healthcare administration, medical management, physician executive, leadership

At one time it was believed that career pathways did not exist for physicians, that they would simply dedicate themselves to a lifetime of practice. ${ }^{1}$ But the truth is that physicians often change specialties and alter their career plans in significant ways. A study of 603 individuals who graduated medical school from the University of Calgary between 1973 and 1985 found that $29 \%$ of physicians changed specialties after entering practice. Thus, decisions made during residency are not necessarily final with respect to later career choices. ${ }^{2}$ Dr Leonard Laster, a physician who has been a laboratory scientist and CEO of two academic medical centers, observed that there are essentially five career pathways in medicine: ${ }^{3}$

1. Primary Care

2. Surgery

3. Psychiatry

4. Disciplines removed from ongoing care (anesthesiology, pathology, radiology)

5. Pursuits distanced from clinical practice (insurance, pharmacy, politics, law, research, administration, informatics, consulting, writing, performing arts, entrepreneurship).

Only a small percentage of physicians choose administration and management as a specialty, but many physicians have administrative responsibilities associated with their clinical practice. Administrative medicine is not recognized by the American Board of Medical Specialties as a specialized field of practice. In the United States, many physicians with administrative roles are dues-paying members of the American College of Physician Executives (ACPE), the national professional society representing physicians in management. The mission of ACPE is "lifelong growth and support of physician leaders" (http://www.acpe.org). 
Physicians who take the plunge into administration generally spend $50 \%$ or more of their time in management activities. Physician managers, and especially physician executives, tend to disengage from full-time practice over time because the priorities of taking care of patients often compete with the priorities of managing healthcare systems, especially for physicians working in the "C" (corporate) suite (for example, chief medical officer, chief executive officer, etc.). ${ }^{4}$

Physicians usually enter administrative medicine for positive reasons, for example, to have a broad impact on healthcare policy and to ensure quality in health care. Physicians who enter administration as an escape from practice may be deceiving themselves if they believe the grass is greener on the management side. To become an accomplished administrator, physicians must have a working knowledge of management science and a keen interest in managing and developing people. Additional qualities include being persuasive, communicating effectively, possessing credibility and trustworthiness, and leading with authority. ${ }^{5}$ The Table summarizes other important qualities and issues physicians should consider before deciding if management is right for them.

\section{Important career events}

Rock musician Neil Finn stated, "You never entirely create your own fate or your own life, but there are choices you make at certain times that dictate what level of success you're comfortable with and feel is positive." ${ }^{.6}$ So it is with physicians, because once they decide to pursue a career in management, and sometimes even before that decision is made, certain events may shape and possibly limit their career potential. ${ }^{7}$

Most important is a physician's choice of primary specialty. No particular field of medicine appears to groom physicians for management better than any other field, although it has been argued that psychiatrists, by virtue of their training in psychotherapy, are more capable than other physicians of managing people. ${ }^{8}$ On the other hand, the decision to specialize in psychiatry may limit employment opportunities of psychiatrists to the mental healthcare sector. Psychiatrists are frequently passed over for management positions requiring a primary care background in the belief that they cannot function as "generalists."

Surgeons may be subjected to discrimination based on stereotypes that portray them as impulsive and quicktempered. And while pathologists may make excellent physician executives, they may lack the necessary support and encouragement to pursue a career in administration. Dr Ralph A Korpman, a pathologist, pointedly asks, "Can it be that physicians in other specialties have, as a group, recognized the future importance of administrative medicine in advance of pathologists"??

Any physician who decides to enter the field of medical management must decide whether to work in a clinical setting (for example, hospital or health system) or in the life sciences industry (for example, health insurance, biotechnology, or pharmaceutical company). Once a physician has spent significant time in industry, it may be difficult to return to a clinical setting, either as an administrator or full-time practitioner. The reasons for this vary and may include an attenuation of clinical skills, a lack of desire to return to practice, and the possibility that it will be difficult to reorient industry-based physicians to a practice environment.

\section{Business education}

Sooner or later, physicians in management will ask themselves whether they should pursue a graduate degree in business administration. Doctors should earn business degrees

Table I Is administrative medicine a good fit? ? $^{3}$

\begin{tabular}{ll}
\hline Issue & Requirement \\
\hline Qualifications & Extremely good knowledge of clinical medicine; board certified; ethically grounded; good business sense (MBA a plus) \\
Ego strength & $\begin{array}{l}\text { Able to withstand isolation; take an unpopular position and stand for it; secure enough to have a separate identity } \\
\text { from full-time practicing physicians }\end{array}$ \\
Interpersonal skills & Skillful communicator; team player; interested in managing and influencing people; persuasive and willing to confront \\
& people \\
Philosophy & Belief in oneself as a change agent; concerned primarily about quality of care rather than hard dollars \\
Motivation & Seeks administration for positive reasons; a "chosen" path rather than an escape from medicine \\
Data orientation & Detail oriented; use of analytic constructs; not "numbers blind" \\
Organizational variables & Able to work within large organizations; understands organizational hierarchy and dynamics; embraces organizational \\
Leadership & sense of purpose
\end{tabular}

Abbreviation: MBA, master of business administration. 
to tackle the ills of the health system and not because they think an MBA degree automatically opens doors. Business school provides the requisite skills to manage the "medicalindustrial complex,"10 and it teaches physicians the language of business. ${ }^{11}$ No matter how clinically astute a physician may be, clinical experience alone cannot substitute for formal training in business and management.

Increasingly, organizations are seeking physician executives with an MBA or similar degree, or at least some type of training in management on a non-traditional basis. A variety of programs are tailored to physicians, including accelerated executive MBA programs and distance-learning programs (via the Internet). A detailed discussion of these programs is beyond the scope of this article; however, it is incumbent upon physicians who have an interest in administrative medicine to thoroughly investigate their options. Physicians need to be well versed in the key aspects of healthcare administration, such as accounting and finance, operations management, human resources administration, strategic management, and the information sciences. Although large medical institutions may provide physicians with in-house learning opportunities, including physician leadership programs, ${ }^{12}$ physicians cannot rely solely on their employer for their education.

\section{Management realities}

Physicians who enter the field of administration will quickly be confronted by a few harsh realities. ${ }^{13}$ They will be far outnumbered by non-physician executives, and thus the "playing field" will not be level. They are likely to be viewed as turncoats by colleagues and as outsiders by lay administrators. Physician executives have a foot in two different worlds - one in clinical practice and one in business management - but not $100 \%$ in either world. Private practice physicians may make derisive comments, such as, "You have joined the dark side (enemy, suits, etc.).” Most assuredly, physician executives will have less autonomy than they had in practice, and they may have a boss who is not a physician. Some physicians may have salary expectations or needs that are out of step with industry standards. Job security for physician executives is tenuous, with turnover rates estimated at $10 \%$ annually, ${ }^{14}$ compared with $6.1 \%$ for practicing physicians in $2007 .{ }^{15}$

Just as certain minority groups experience a "glass ceiling" that inhibits their upward mobility, physicians are likely to encounter several obstacles when attempting to move to a higher level of management, the so-called "caducean ceiling." " An online survey of 687 members of the American College of Physician Executives, conducted in 2003, revealed that a lack of operational experience prevented more than a third of physicians from attaining greater employment status. Another factor was the lack of a formal education in business management, reported by $23 \%$ of respondents. Interestingly, $14 \%$ of physicians believed there were no barriers to their careers, and $6 \%$ of physicians had no desire to be promoted to a higher level of management. One out of five physicians believed that their career mobility was thwarted by the fact they were physicians!

Another survey ${ }^{17}$ of ACPE members, conducted in 2000 with 620 physicians, sought to determine how many of them had been involuntarily terminated from a medical management job. Nearly half had been terminated within the past 5 years. Reasons included personal conflicts, downsizing, mergers, and financial losses sustained by their organizations. Physicians were also vulnerable to job loss when their immediate supervisors had been terminated. The departure of one's boss often signals impending changes at lower levels of the organization. Physicians who have worked for organizations embroiled in legal investigations and litigation have also been engulfed by winds of change. ${ }^{18}$

In many cases, however, physicians in management lose their jobs because of personal failure. Inadequate appreciation of job tasks; inertia in task completion; reluctance to confront issues and people; failure to communicate effectively; lack of involvement in business operations; inability to accept criticism; and setting goals that are not aligned with the organization are common reasons for failure. ${ }^{19}$

In order to ensure alignment between personal goals and organizational goals it is important for physicians to share their company's vision and mission. ${ }^{20}$ This may require considerable adjustment, especially for physicians working in for-profit organizations, where traditional patient-centered ethical principles may clash with business goals and objectives. Dr Steven Sharfstein, a noted physician executive and former president of the American Psychiatric Association, commented, "....the fact that profit-making motives of industry come into conflict with professional ethics is amply documented and should come as no surprise...."21

Physician executives may also clash with lay administrators who have management goals other than medical standards. Relationships between physician executives and non-physician executives have been rife with conflict for years, and these conflicts may not dissipate easily given the broader scope of administrative responsibilities sought by and accorded physician executives nowadays. The boundaryspanning roles of physician executives puts them in direct competition for coveted CEO positions once considered the sole province of non-physician executives. Also, physicians 
and non-physician executives have been trained differently, and their personalities are often polar opposites. ${ }^{22}$ Despite these differences, however, it appears that the contributions of physician executives are genuinely appreciated by nonphysician executives, who consistently rate the value of physician executives to organizational performance higher than physician executives rate themselves! ${ }^{23}$

\section{Dealing with job loss}

Physician executives who lose their jobs must take immediate action because the job market for healthcare leadership positions is becoming increasingly crowded. It is generally recommended that physicians adhere to a few basic principles when leaving one job for another one, regardless of the reason for termination. ${ }^{24}$ First, they should agree on the "parting line" with their boss before actually leaving their position (a letter of recommendation may be required for the next job). Second, physicians should not blame themselves or their former organization for parting ways, and they should never "trash" the company to anybody. Third, physicians should not feel ashamed that they lost their job, or try to hide from family and friends. The people with whom they are the closest may be their biggest source of comfort until they find another job. Fourth, they should begin searching for a new job right away, but avoid the temptation to accept the first job offer unless it appears to be a very good fit. At the same time, physicians should not be overly specific and demanding in their search.

New job opportunities are likely to materialize when physicians network with colleagues and executive job recruiters, as opposed to perusing classified advertisements. There will also be more opportunities for physicians who are willing to relocate for a new position. In fact, studies have shown that physician executives are highly mobile and typically require a willingness to move between organizations and across organizational types to advance their careers. ${ }^{25}$

The time between jobs provides physicians an excellent opportunity to update their resumes, reassess their strengths and weaknesses, and obtain or reinvest in critical core competencies. ${ }^{26}$ They should seek out mentors and practice rehearsing for job interviews, specifically by formulating answers to questions they are likely to be asked during an interview. Companies seeking the services of physician executives typically employ performance-based interviewing methods to assess a candidate's skills. ${ }^{27}$ Examples of questions commonly asked are:

- What strategies have candidates used in the past to build consensus on teams?
- Can candidates convey unpopular decisions to subordinates and senior leaders? Can they give an example from their past. Were they able to persuade anyone to their point of view?

- What was the most difficult personnel (or budgeting) challenge the candidate ever faced, and how did he or she handle it?

- What was the most successful project ever led by the candidate? Specifically describe the candidate's role.

Physicians, like all other job candidates, must make sure they conduct themselves professionally, treating everyone with respect and kindness, especially people responsible for arranging interviews and working behind the scenes. Personal interactions (soft skills) will figure prominently in hiring decisions. ${ }^{28}$ Abrasive physicians and those who have a reputation for being difficult and disruptive will undoubtedly be bypassed. Above all, leadership skills will be evaluated and considered highly valuable.

\section{Physician leadership}

Health care systems that are serious about transforming themselves must harness the energies of physicians as organizational leaders. However, there are many challenges in developing physicians as leaders for management. A recent McKinsey report ${ }^{29}$ identified the following three barriers to effective clinical leadership: (1) the devaluation of administration compared with direct patient care; (2) the lack of incentives for physicians to take on leadership roles; and (3) the lack of provisions for the nurturing of clinicalleadership capabilities, including the failure to allocate educational and professional development resources. Despite these challenges, the report extolled the virtues of clinical leadership and cited examples of physicians who lead as service line managers and frontline managers, as well as physicians who lead at the corporate level.

Physician leaders in the life sciences industry tend to have less visible and formal leadership roles than their counterparts in the clinical arena. An applied leadership style is more typical of industry physicians in that they are often called on to support the commercial objectives of the organization. In the pharmaceutical industry, for example, key leadership roles for physicians exist in research and development and drug safety evaluation and monitoring. These areas rest on a firm foundation of medical science and fuel the commercial operations. However, the core business functions - sales and marketing - are typically led by non-physician executives.

Whether managing in the clinical setting or in industry, the skills physicians have acquired in medical school 
and residency are not easily transferrable to management and leadership roles. Dr Michael B Guthrie, a prominent physician executive, has identified several skill sets required for effective medical leadership. Among them are the ability to manage change, improvement, and performance outcome. ${ }^{30}$ Managing information is also important. Guthrie concludes, "To achieve these skills, the aspiring physician leader must first be able to change himself to become an effective instrument of change with other physicians."

Healthcare reform is once again on the national agenda, and organizations are trying new methods of responding to market changes, often pressing reset on their management structure. Physicians can be a strong force for management change, and those with leadership qualities can actually be the drivers of change. As more and more organizations recognize the value of physician executives, they will seek physicians with the best leadership skills to fill newly created positions in the private and public private sectors.

\section{Disclosure}

The author reports no conflicts of interest in this work.

\section{References}

1. Gumbiner R. Perspectives of an HMO leader. Inquiry. 1994;31(3): 330-333.

2. Jennett PA, Kishinevsky M, Bryant H, Hunter KL. Major changes in medical careers following medical school graduation: when, how often, and why. Acad Med. 1990;65(1):48-49.

3. Laster L. Life After Medical School. New York, NY: Norton \& Company; 1996.

4. Rogers M. Wearing two hats. HealthLeaders. 2003;6(1):69-70.

5. Cors WK. The chief medical officer: a critical success factor. Physician Exec. 2009;35(5):60-62.

6. Lloyd R. Whistling tunes: Neil Finn escapes a crowded house. LA Weekly, July 11, 2002. Available from: http://www.laweekly.com/2002-07-11/ music/whistling-tunes. Accessed on August 10, 2009.

7. Lazarus A. Defining events in the careers of physician executives. Physician Exec. 2005;31(5):36-39.

8. Penzer WN. Clinician turned administrator: drawing upon clinical experience for managerial expertise. Adm Policy Ment Health. 1989; 17:105-109.

9. Korpman RA. The pathologist as physician executive (editorial). Arch Pathol Lab Med. 1988;112:579.
10. Hillman AL, Nash DB, Kissick WL, Martin SP. Managing the medical-industrial complex. N Engl J Med. 1986;315:511-513.

11. Lazarus A. MD/MBA: Physicians on the New Frontier of Medical Management. Tampa, FL: American College of Physician Executives; 1996.

12. Scott HM, Tangalos EG, Blomberg RA, Bender CE. Survey of physician leadership and management education. Mayo Clin Proc. 1997;72: 659-662.

13. Lyons MF, Cejka S. Getting a firm grip on the realities for physician executives. Physician Exec. 1994;20(6):8-12.

14. Tiffan WR. Health care downsizing: a survival guide. Physician Exec. 1995;21(9):22-23.

15. 2008 Physician Retention Survey. Cejka Search and American Medical Group Association.

16. Weber DO. 'Caducean ceiling' blocks docs from CEO posts. Physician Exec. 2002;28(5):6-9.

17. Kirz H. Congratulations...you're fired! Physician Exec. 2000;26(4): 20-25.

18. Lazarus A. Can you recognize the winds of change? Physician Exec. 2007;33(5):30-33.

19. Peters RM. When Physicians Fail as Managers. Tampa, FL: American College of Physician Executives; 1994.

20. Lazarus A. Reality check: is your behavior aligned with organizational goals? Physician Exec. 2004;30(5):50-52.

21. Sharfstein SS. Comments on "presidential address: advocacy to leadership" (Dr Sharfstein's reply). Am J Psychiatry. 2007;164(2):346.

22. O'Connor SJ, Shewchuk RM. Enhancing administrator-clinician relationships: The role of psychological type. Health Care Manage Rev. 1993;18(2):57-65.

23. Dunham NC, Kindig DA, Schulz R. The value of the physician executive role to organizational effectiveness and performance. Health Care Manage Rev. 1994;19(4):56-63.

24. Lazarus A. What threatens psychiatric administrators' job security? Psychiatr Serv. 2002;53:1018-1022.

25. Kindig DA, Dunham NC, Chun LM. Career paths of physician executives. Health Care Manage Rev. 1991;16(4):11-20.

26. Lazarus A. Cultivate your core competencies. Physician Exec. 2002;28(3):34-38

27. Lazarus A. Preparation is key to successful job interviews. Physician Exec. 2004;30(3):48-50.

28. Lazarus A. Soften up: the importance of soft skills for psychiatrist executives. Psychiatrist Admistrator. 2004;4(1):19-23.

29. Mountford J, Webb C. When Clinicians Lead. The McKinsey Quarterly, February 2009. Available from: http://www.ra.mahidol.ac.th/files/file/ 0pp/When\%20Clinicians\%20Lead.pdf Accessed on August 10, 2009.

30. Guthrie MB. Challenges in developing physician leadership and management. Front Health Serv Manage. 1999;15(4):3-26.

31. Ottensmeyer DJ, Key MK. Lessons learned hiring HMO medical directors. Health Care Manage Rev. 1991;16(2):21-30.
Journal of Healthcare Leadership

\section{Publish your work in this journal}

The Journal of Healthcare Leadership is an international, peer-reviewed, open access journal focusing on leadership for the health profession. The journal is committed to the rapid publication of research focusing on but not limited to: Healthcare policy and law; Theoretical and practical aspects healthcare delivery; Interactions between healthcare and society and evidence-based practices;

\section{Dovepress}

Interdisciplinary decision-making; Philosophical and ethical issues; Hazard management; Research and opinion for health leadership; Leadership assessment. The manuscript management system is completely online and includes a very quick and fair peer-review system. Visit http://www.dovepress.com/ testimonials.php to read real quotes from published authors. 